\title{
FUZZY-ANP BASED RESEARCH ON THE RISK ASSESSMENT OF BIOGAS PRODUCTION FROM AGRICULTURE BIOMASS
}

\author{
Sandija Zeverte-Rivza* \\ Latvia University of Agriculture \\ Jelgava, Latvia \\ E-mail: Sandija.Rivza@1lu.lv \\ Peteris Rivza \\ Latvia University of Agriculture \\ Jelgava \\ Latvia \\ E-mail: Peteris.Rivza@1lu.lv
}

\begin{abstract}
Due to the European Union policy in promotion of the use of renewable resources for energy production, biogas production from agriculture biomasses is becoming more popular in Latvia. At the moment there are 32 biogas stations that produce biogas from agriculture biomass, and building of around 20 more is planned. Biogas production from agriculture biomass includes several complicated processes: growing of green biomass; preparation and storage of biomass for use in the reactor; running of the biogas plant, and monitoring of biogas production; cogeneration and use of the produced electricity and heat, and utilization of digestate. All these production processes are affected by various risks that can be divided into several groups: personnel, production, property, logistic, environment and legislative. In the present research risks were identified by experts and producers of biogas. Besides identifying the risks, biogas producers also evaluated the probability that the risk event will occur as well as the potential significance of the consequences of risk occurrence. The use of the Fuzzy-Analytic Network Process (ANP) method gave a possibility of evaluating the mutual impact of risks as well as the risk management alternatives.
\end{abstract}

Keywords: Analytic Network Process (ANP), Fuzzy-ANP, risk assessment, biogas production.

\section{Introduction}

Following the world tendencies, the topicality of renewable energy production in Latvia is increasing. Currently, most of the electricity from renewable resources in Latvia is obtained from hydropower plants, but $1 \%$ of electricity is produced by cogeneration of biomass, which is seen as a perspective source for increasing renewable energy production while utilising food and agriculture waste, thus contributing to the sustainability principles of the production cycle. The development of biogas production plants is largely encouraged by funding from the EU structural funds, Cohesion fund, and European Agriculture Fund for Rural Development available from the government of Latvia and the EU in the past few years (Rivza, 2012).

\footnotetext{
* Corresponding author
}

Acknowledgement: Publication and dissemination of research results have been made due to the funding of the ESF Project „Support to the implementation of doctoral studies in the Latvia University of Agriculture”, Contract No. 2011/0055/1DP/1.1.2.1.2/11/IPIA/VIAA/008. 
At the moment there are 38 biogas production plants working in the territory of Latvia -6 of them are producing biogas from waste and sewage sludge and 32 produce biogas from agriculture biomasses. In 2012, biogas stations produced $214.34 \mathrm{GWh}$ of electricity, which is a rather big increase compared to the $100.96 \mathrm{GWh}$ produced in 2011 (Figure 2). Such increase in production was made because of the support mechanisms for renewable energies - above-mentioned EU funding for investments in building biogas production plants and advantageous purchase tariffs for the produced energy.

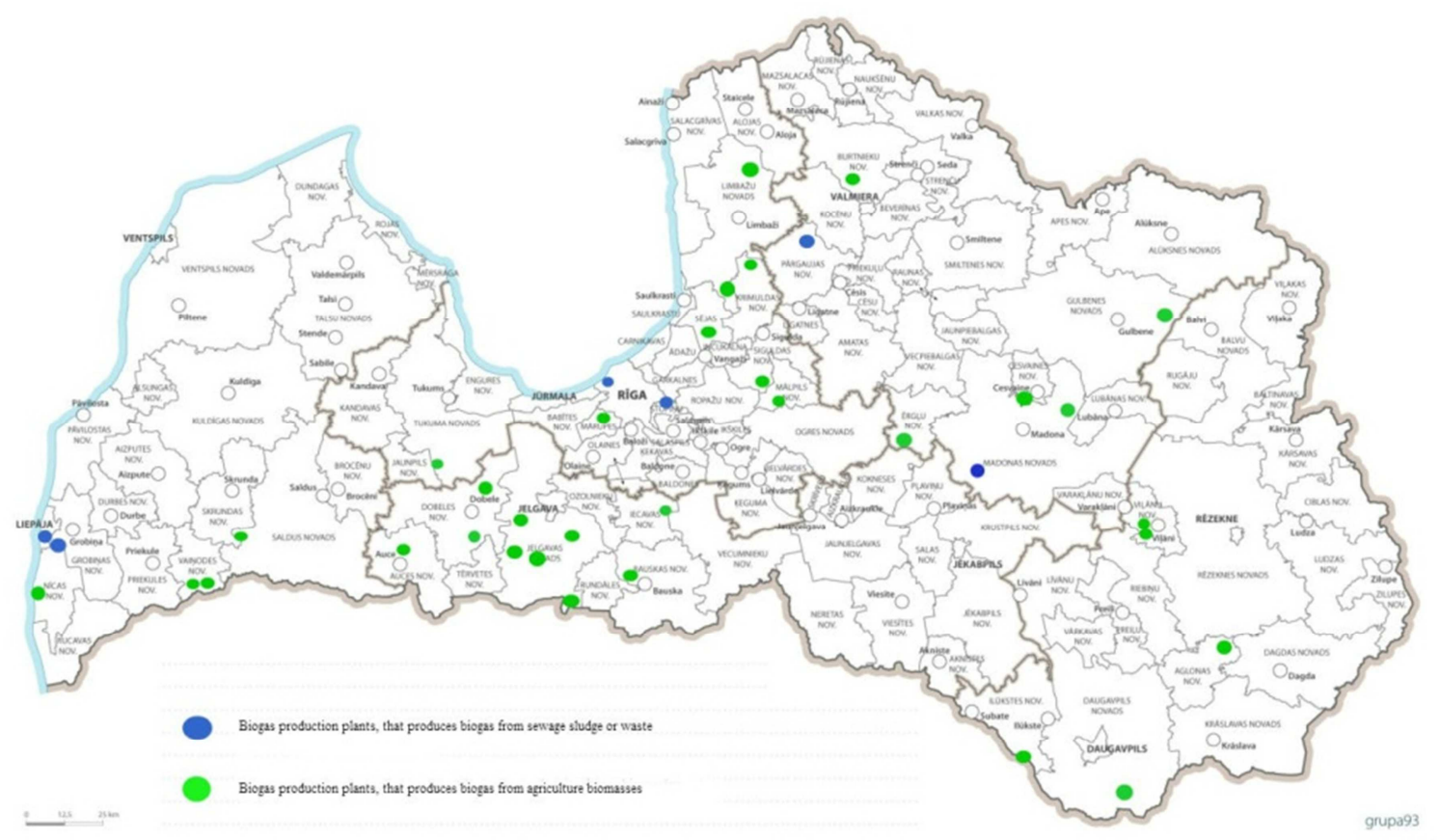

Source: made by the authors, using data of the Ministry of Economics of the Republic of Latvia.

Figure 1. The mapped location of the biogas production plants in Latvia.

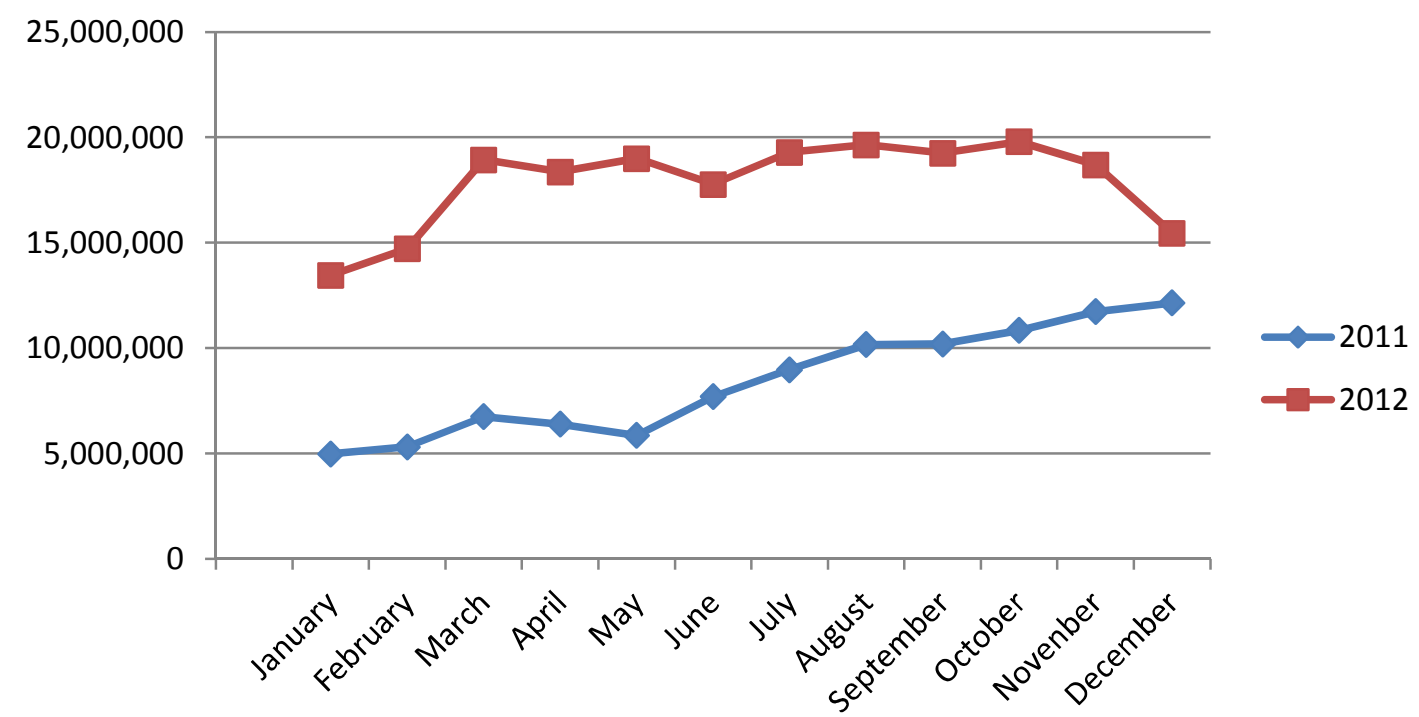

Source: made by the authors, using data of the Ministry of Economics of the Republic of Latvia.

Figure 2. The dynamics of electricity produced from the biogas in Latvia in the years 2011 and 2012, KWh.

As biogas production is a new sector in Latvia, there are several risks, that that have not yet been studied and defined, and an attention should be paid to the estimation of the significance of these risks and to the choice of risk management alternatives. 


\section{Methods and Results}

The input data for the use of Fuzzy-ANP was obtained from the risk evaluation performed in the 15 biogas production plants that produce biogas from agriculture biomasses. The risk evaluation form was prepared by the authors of the paper together with three experts - two producers of biomass and one representative of the Latvia Biogas Association. The evaluation form included 24 risks that were divided into six groups: personnel, production, property, logistic, environment and legislative risks.

The risk evaluation form was based on the literature review showing that the risk classification in this field is mostly related to the cause of risk. Dominating groups among others are technological, environmental, legislative, financial and investment risk groups (Olivier, s.a., Financial Risk Management, 2004, Froggatt, Lhan, 2010., Ferraris, s.a.), less common are such groups as social, macroeconomic, resource, short-term and long-term operating risks and reputation risks (Financial Risk Management, 2004, Froggatt, Lhan, 2010, Aragonés-Beltrán, Pastor-Ferrando, 2009).

Table 1. Classification of assessed risks.

\begin{tabular}{|l|l|}
\hline \multicolumn{1}{|c|}{ Risk group (cluster) } & \multicolumn{1}{|c|}{ Risk } \\
\hline 1.Personnel & 1.1.Responsibility of the personnel \\
& 1.2. Qualification and experience \\
1.3. Work safety violations
\end{tabular}

Source: made by the authors. 
Experts were asked to assess the probability of the risks to occur in the scale of 1 - 5 points (from unlikely to frequent), to assess the potential losses of the risk occurrence in the scale of $1-5$ points (from negligible to catastrophic) and choose one or several risk management alternative for each risk form the list of five alternatives (Rivža, 2012) - risk avoidance, risk reduction; risk acceptance, risk transfer and diversification.

After obtaining the results from the expert evaluation, the linguistic scale, in which the probability and significance of risks were assessed, was transferred into triangular fuzzy scale as shown in Tables 2 and 3 .

Fuzzy set theory was first developed by Zadeh in 1965. He was attempting to solve fuzzy phenomenon problems, including problems with uncertain, incomplete, unspecific, or fuzzy situations. (An Integrated approach..., 2012). The concept of fuzzy numbers originates from the fact that many qualitative phenomena in the real world cannot be expressed by precise and certain numbers (Ranjbar, Khatami, et.al., 2006, Zegordi, et.al., 2012). Fuzzy set theory is more advantageous than traditional set theory when describing set concepts in human language. It allows us to address unspecific and fuzzy characteristics by using a membership function that partitions a fuzzy set into subsets of members that "incompletely belong to" or "incompletely do not belong to" a given subset (An Integrated approach..., 2012).

In this study fuzziology was used to process the judgements of the experts and get values for further use in the ANP. Although combining the use of Fuzzy numbers with decision making methods is criticised (Saaty, Tran, 2007, Saaty, Tran, 2010), in this case it was used to make the transition from the two risk evaluation linguistic values for probability and significance of each risk to one defuzzification value that can be used for further calculations.

The most suitable for our research was the triangular fuzzy function due to its applicability in representing the particular linguistic variables and simplicity in modelling easy interpretations (Torfi, et al., 2010). It can be described with the following mathematical expression (Ross, 2005):

$$
\mu_{A}(x)=\left\{\begin{array}{ll}
0 & \text { if } x \leq a \\
\frac{x-a}{b-a} & \text { if } a \leq x \leq b \\
\frac{c-x}{c-b} & \text { if } b \leq x \leq c \\
0 & \text { if } x \geq c
\end{array}\right\}
$$

Table 2. Triangular fuzzy scale for evaluation of the probability of risks.

\begin{tabular}{|l|l|l|}
\hline Linguistic scale & Characterization & Triangular fuzzy scale \\
\hline Unlikely & $\begin{array}{l}\text { Could happen only under } \\
\text { rare conditions }\end{array}$ & $(0,0.125,0.25)$ \\
\hline Seldom & $\begin{array}{l}\text { Could happen though } \\
\text { unlikely }\end{array}$ & $(0.15,0.30,0.45)$ \\
\hline Occasional & $\begin{array}{l}\text { Could happen during one } \\
\text { year }\end{array}$ & $(0.35,0.50,0.65)$ \\
\hline Likely & $\begin{array}{l}\text { Could happen once in } \\
\text { several month }\end{array}$ & $(0.55,0.70,0.85)$ \\
\hline Frequent & $\begin{array}{l}\text { Mostly happens at least } \\
\text { once a month }\end{array}$ & $(0.75,0.875,1.0)$ \\
\hline
\end{tabular}

Source: made by the authors. 
Table 3. Triangular fuzzy scale for evaluation of the significance of risks.

\begin{tabular}{|l|l|l|}
\hline Linguistic scale & Characterization & Triangular fuzzy scale \\
\hline Negligible & $\begin{array}{l}\text { Up to } 1 \% \text { from the total } \\
\text { budget of the enterprise }\end{array}$ & $(0,0.0075,0.015)$ \\
\hline Minor & $\begin{array}{l}1-5 \% \text { from the total } \\
\text { budget of the enterprise }\end{array}$ & $(0.005,0.025,0.055)$ \\
\hline Moderate & $\begin{array}{l}5-10 \% \text { from the total } \\
\text { budget of the enterprise }\end{array}$ & $(0.045,0.0775,0.11)$ \\
\hline Critical & $\begin{array}{l}10-25 \% \text { from the total } \\
\text { budget of the enterprise }\end{array}$ & $(0.09,0.195,0.30)$ \\
\hline Catastrophic & $\begin{array}{l}\text { Above } 25 \% \text { from the total } \\
\text { budget of the enterprise }\end{array}$ & $(0.20,0.60,1.0)$ \\
\hline
\end{tabular}

Source: made by the authors.

After defining the fuzzy scale for significance and probability, it should be connected with both risk evaluation elements. From the analysis of the scientific literature on the notion of risk (Hardaker, Huirne, 2004, Baoding, 2011, etc.) and the principles of risk definitions by German sociologist Ortwin Renn (Renn, 2008) authors suggest the following definition of the term "risk":

Risk is the multiplication of the probability of an event occurrence and its significance level of potentially unfavourable consequences.

This can be mathematically described as:

$$
\text { Risk }=\text { Probability }(\text { of an event }) \times \text { Significance }(\text { loss })
$$

And if, in compliance with the equation (2), the two fuzzy functions of probability and significance are multiplied (Meixner, 2009), the risk as a fuzzy function value is obtained (Table 3). In such a way the risk becomes a fuzzy function, but in order to use these variables further on, the defuzzification process was done - for each fuzzy value a scalar value was calculated using the centroid method (Ross, 2005). For this purpose we used MATLAB Fuzzy Logic Toolbox (Defuzzification Methods, 2013).

Table 4. Risk defuzzification.

\begin{tabular}{|l|l|l|}
\hline Linguistic scale & Triangular fuzzy scale & $\begin{array}{l}\text { Defuzzification } \\
\text { value }\end{array}$ \\
\hline Unlikely with negligible loss & $(0,0.00187,0.00375)$ & 0.0019 \\
\hline Unlikely with minor loss & $(0,0.00687,0.01375)$ & 0.0069 \\
\hline Unlikely with moderate loss & $(0,0.01375,0.02750)$ & 0.0138 \\
\hline Unlikely with critical loss & $(0,0.03750,0.0750)$ & 0.0375 \\
\hline Unlikely with catastrophic loss & $(0,0.1250,0.250)$ & 0.125 \\
\hline Seldom with negligible loss & $(0,0.00337,0.00675)$ & 0.0034 \\
\hline Seldom with minor loss & $(0.00075,0.01275,0.02475)$ & 0.0128 \\
\hline Seldom with moderate loss & $(0.00675,0.02812,0.04950)$ & 0.0281 \\
\hline Seldom with critical loss & $(0.01350,0.07425,0.1350)$ & 0.074 \\
\hline Seldom with catastrophic loss & $(0.030,0.240,0.450)$ & 0.2400 \\
\hline Occasional with negligible loss & $(0,0.00487,0.00975)$ & 0.0049 \\
\hline Occasional with minor loss & $(0.00175,0.01875,0.03575)$ & 0.0188 \\
\hline Occasional with moderate loss & $(0.01575,0.04362,0.07150)$ & 0.0436 \\
\hline Occasional with critical loss & $(0.03150,0.12325,0.1950)$ & 0.1133 \\
\hline Occasional with catastrophic loss & $(0.070,0.360,0.650)$ & 0.3600 \\
\hline Likely with negligible loss & $(0,0.00637,0.01275)$ & 0.0064 \\
\hline
\end{tabular}


Continuation of Table 4.

\begin{tabular}{|l|l|l|}
\hline Linguistic scale & Triangular fuzzy scale & $\begin{array}{l}\text { Defuzzification } \\
\text { value }\end{array}$ \\
\hline Likely with minor loss & $(0.00275,0.02475,0.04675)$ & 0.0248 \\
\hline Likely with moderate loss & $(0.02475,0.05912,0.09350)$ & 0.0591 \\
\hline Likely with critical loss & $(0.04950,0.15225,0.2550)$ & 0.1522 \\
\hline Likely with catastrophic loss & $(0.110,0.480,0.850)$ & 0.4800 \\
\hline Frequent with negligible loss & $(0,0.0075,0.0150)$ & 0.0075 \\
\hline Frequent with minor loss & $(0.00375,0.02937,0.0550)$ & 0.0294 \\
\hline Frequent with moderate loss & $(0.03375,0.07187,0.110)$ & 0.0719 \\
\hline Frequent with critical loss & $(0.0675,0.1837,0.30)$ & 0.1838 \\
\hline Frequent with catastrophic loss & $(0.150,0.5750,1.00)$ & 0.5750 \\
\hline
\end{tabular}

Source: made by the authors.

Defuzzification value was then determined for each of the previously evaluated risks by two elements of risk evaluation - probability and significance (Tables 4) and adapted to the particular risk evaluation (Table 5) by calculating modal evaluation values for significance and probability from the expert evaluation for each of the 24 evaluated risks and finding the respective defuzzification value from the Table 4.

Table 5. Fuzzy values.

\begin{tabular}{|c|c|c|c|c|}
\hline \multirow[t]{2}{*}{ Risk group (cluster) } & \multirow[t]{2}{*}{ Risk } & \multicolumn{2}{|c|}{ Mode (from the survey) } & \multirow[t]{2}{*}{ Defuzzification value } \\
\hline & & Probability & Significance & \\
\hline \multirow[t]{3}{*}{ 1.Personnel } & 1.1 . & Occasional & Minor & 0.0188 \\
\hline & 1.2 . & Seldom & Minor & 0.0128 \\
\hline & 1.3 . & Unlikely & Minor & 0.0069 \\
\hline \multirow[t]{8}{*}{ 2.Production } & 2.1. & Occasional & Critical & 0.1133 \\
\hline & 2.2 . & Occasional & Critical & 0.1133 \\
\hline & 2.3 . & Occasional & Critical & 0.1133 \\
\hline & 2.4. & Likely & Catastrophic & 0.4800 \\
\hline & 2.5 . & Occasional & Catastrophic & 0.2400 \\
\hline & 2.6 & Likely & Catastrophic & 0.4800 \\
\hline & 2.7 . & Unlikely & Negligible & 0.0019 \\
\hline & 2.8 . & Occasional & Minor & 0.0188 \\
\hline \multirow[t]{4}{*}{ 3.Property } & 3.1. & Unlikely & Negligible & 0.0019 \\
\hline & 3.2 . & Unlikely & Catastrophic & 0.125 \\
\hline & 3.3 . & Occasional & Catastrophic & 0.2400 \\
\hline & 3.4. & Seldom & Catastrophic & 0.0049 \\
\hline \multirow[t]{5}{*}{ 4.Logistic } & 4.1. & Occasional & Critical & 0.1133 \\
\hline & 4.2 & Unlikely & Moderate & 0.0138 \\
\hline & 4.3 . & Unlikely & Negligible & 0.0019 \\
\hline & 4.4. & Unlikely & Negligible & 0.0019 \\
\hline & 4.5 . & Unlikely & Negligible & 0.0019 \\
\hline \multirow[t]{2}{*}{ 5.Environment } & 5.1. & Occasional & Negligible & 0.0049 \\
\hline & 5.2 . & Unlikely & Negligible & 0.0019 \\
\hline \multirow[t]{2}{*}{ 6.Legislative } & 5.1. & Frequent & Catastrophic & 0.5750 \\
\hline & 5.2 . & Frequent & Catastrophic & 0.5750 \\
\hline
\end{tabular}

Source: made by the authors. 
Table 6. Supermatrix reflecting connections of two risk groups - Personnel risks and Production risks.

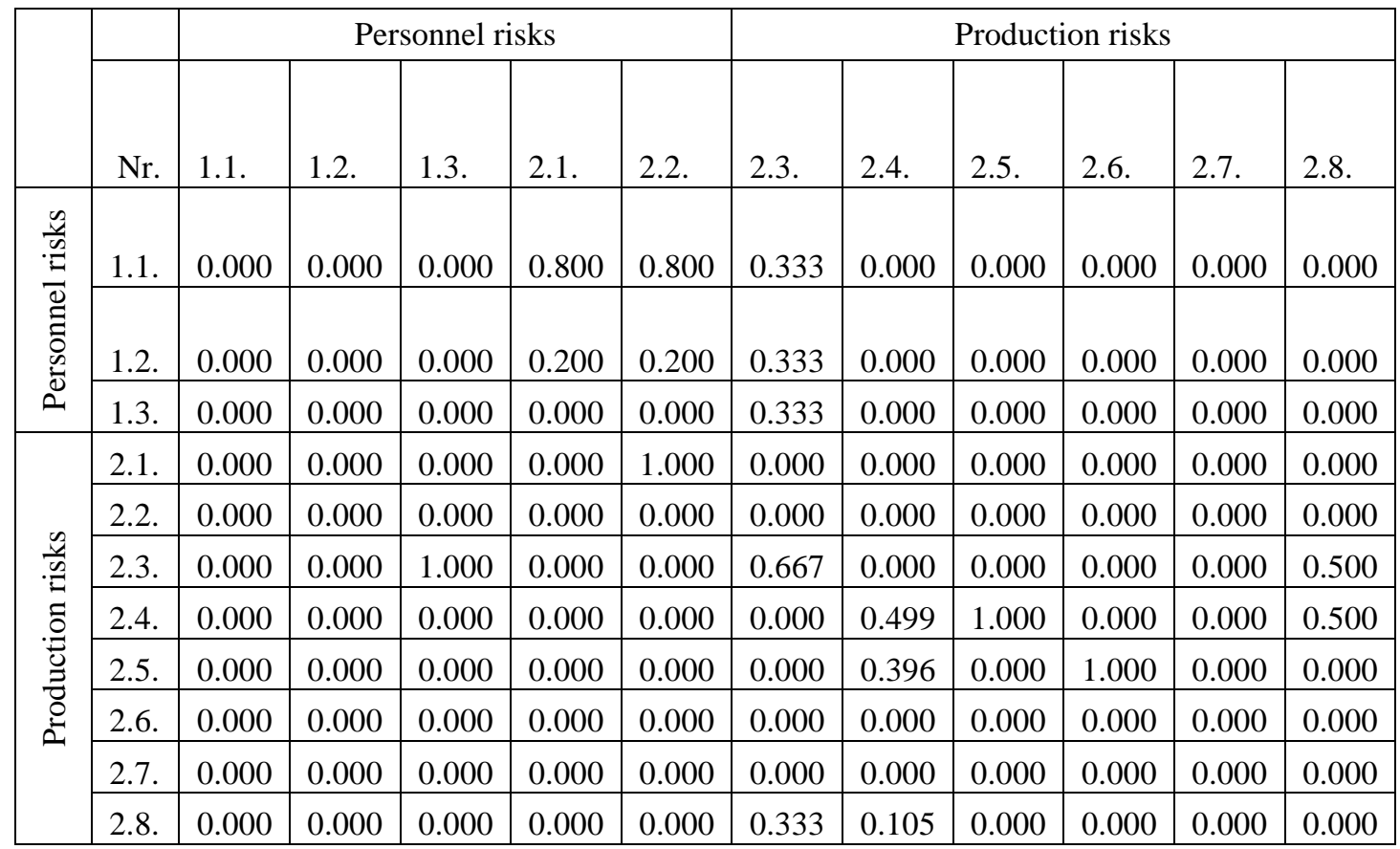

Source: made by the authors using superdecisions.com software

The ANP was performed using superdecisions.com software, the module of all risk groups (see Table 1) as clusters and risks as nodes in those clusters were formulated and connected with the unilateral and multilateral connections between and within clusters, depending on logical connectivity of these risks. The evaluation was made with the acquired defuzzification values that were transferred into the 1-9 point scale established by prof. Saaty (Saaty, 1990, 2008). When the defuzzification values were adjusted to the nine point scale, the pairwise comparison was done with the risks that had been previously connected within or between the clusters.

Table 6 illustrates the evaluation of risks in two risk groups - Personnel and Production. To use the ANP model further, also the risk management alternatives were evaluated in respect to all the risks in the module, but in the evaluation of alternatives the summed evaluation from experts for the suitability of each alternative for each of the risks is used.

\section{Conclusions}

Sector of biogas production in Latvia is a new sector that is subjected to various risks, therefore comprehensive risk determination and classification is an important precondition to successful and meaningful risk management.

Use of Fuzzy-ANP method in risk management gives an opportunity to perform the risk assessment by including tangible and intangible factors, and to evaluate various dependencies between risks and alternatives, making it a valuable tool for risk assessment.

The use of the fuzzy values for evaluation helps to deal with uncertain, incomplete or unspecific values that are characteristic to risk assessment. In this paper the fuzzy values were used to transfer two linguistic components (probability and significance) of risk evaluation to one value indicating risk level that can be further used in ANP. 


\section{References}

Baoding L. (2011) Uncertainty Theory. Department of Mathematical Sciences. (Accessed on February 15. 2013.) http://www.orsc.edu.cn/ liu/ut.pdf

Defuzzification Methods. MATLAB Fuzzy Logic Toolbox, (2013) .http://www.mathworks.se/ products/fuzzylogic/examples.html?file=/products/demos/shipping/fuzzy/defuzzdm.html (Accessed on February 15. 2013.)

Hardaker, J., Huirne, R.B.M., Anderson, J.R., Lien, G. (2004) Coping with risk in agriculture. Cambridge: CABI, 332.

Meixner, $O$ (2009) Fuzzy AHP Group Decision Analysis and its Application for the Evaluation of Energy Sources. In: Proceedings of the $10^{\text {th }}$ International Symposium on the Analytic

Hierarchy/Network Process Multi-criteria Decision Making, University of Pittsburgh, Pittsburgh, Pennsylvania, USA. (Accessed on February 15. 2013.)

http://www.isahp.org/2009Proceedings/Final_Papers/ 50_Meixner_Fuzzy_AHP_REV_FIN.pdf

Mohaghar A, Fathi M.R., Faghih A., Turkayesh M.M. (2012) An Integrated Approach of Fuzzy ANP and Fuzzy TOPSIS for R\&D Project Selection: A Case Study. In: Australian Journal of Basic and Applied Sciences, 6(2): 66-75.

Renn O. (2008) Concept of Risk: An Interdisciplinary Review. In: Proceedings of the ISA Conference, Barcelona, September 2008, 3-10. (Accessed on February 15. 2013.) http://www.riskanduncertainty.net/TG04/Ortwin_Renn_concepts.pdf

Rivza S., Rivza P. (2012) Conceptual Applications of the Risk Management Measures in Dynamic Models for the Farms Producing Biogas from Agriculture Biomass. In: Proceedings of the AASRI Conference on Power and Energy Systems, Hong Kong, 235-240.

Rivža S., Rivža P. (2012) Risk management in renewable energy production". In: Proceedings of the International Scientific Conference „Renewable Energy and Energy Efficiency”, Jelgava: LLU, pp. 249-254.

Ross T.J. (2005) Fuzzy Logic with Engineering Applications, John Wiley \& Sons Ltd,, 652 (99-101)

Saaty, T.L. (1990). How to make a decision: The Analytic Hierarchy Process. In: European Journal of Operatonal Research, 9-26.

Saaty, T.L. (2008). Decision making For Leaders. The Analytic Hierarchy Process for Decisions in a Complex World, 24-79.

Saaty, T.L., Tran, T. (2007) On the invalidity of fuzzifying numerical judgments in the Analytic Hierarchy Process. In: Mathematical and Computer Modelling. 46, 962-975.

Saaty, T.L., Tran, T. (2010) Fuzzy Judgements and Fuzzy Sets. In: International Journal of Strategic Decision Sciences, 1(1), 23-40. 
Olivier T., Andlug Consulting, Rödl \& Partner (s.a.) Scoping Study on Financial Risk Management Instruments for Renewable Energy Projects. United Nations Environment Programme(Online): Reference document. Marsh and Mc Lennan Companies. p. 142. Available at: http://www.sefi.unep.org/fileadmin/media/sefi/docs/publications/RiskMgt_full.pdf

Ferraris I., De la Canal M.D., Labriola C. (s.a.) Risk Analysis in Renewable Energy: Assessment of the Vulnerability of the Environment and Community. (Online) Available at: http://www.icrepq.com/icrepq07/363-ferraris.pdf

Financial Risk Management Instruments for Renewable energy projects. Summary document. United Nations Environment Programme. Words and Publications, Oxford, UK, 2004, ISBN: 92-807-2445-2

Froggatt A., Lhan G. (2010) Sustainable Energy Security. Strategic Risks and Oppurtunities for Business: White Paper. Lloyds $360^{\circ}$ risk insight. London: Chatman House. p. 48.

Aragonés-Beltrán P., Pastor-Ferrando J.P., Chaparro-González F., Bautista R.P. (2009) Selection of Photovoltaic Solar Power Plant Projects Using ANP. In: Proceedings of the International Symposium on the Analytic Hierarchy Process (Online). Pittsburgh, Pennsylvania, USA. p. 11. Available at: http://www.isahp.org/2009Proceedings/Final_Papers/4_Aragones-Beltran_SOLAR_REV_FIN.pdf

Ranjbar, M., Khatami, R. and Younessi, R., (2006) Prediction of sulfate scale depositions in oilfield operations using arithmetic of LR fuzzy numbers. In: International Journal of Engineering, Transactions B: Applications, Vol. 19, No. 1, 99-106.

Torfi, F., Zanjirani Farahani, R. and Rezapour, S. (2010) Fuzzy AHP to determine the relative weights of evaluation criteria and fuzzy TOPSIS to rank the alternatives. In: Applied Soft Computing, Vol. 10, $520-528$.

Zegordi S. H., Rezaee Nik E., Nazari A. (2012) Power Plant Project Risk Assessment Using a FuzzyANP and Fuzzy-TOPSIS Method. In: International Journal of Engineering, Transactions B: Applications, Vol. 25, No. 2, 107-120. 